\title{
Green Catalysts Activities of CaO Nanoparticles from Pinctada maxima Shell on Alcoholysis Reaction
}

\section{Aktivitas Katalis Hijau Nanopartikel CaO dari kulit Pinctada maxima pada Reaksi Alkoholisis}

\author{
Kendri Wahyuningsih ${ }^{1,2^{*}}$, Jumeri ${ }^{1}$, Wagiman ${ }^{1}$ \\ ${ }^{1}$ Department of Agroindustrial Technology, University of Gadjah Mada \\ Jl. Flora No. 1, Bulaksumur, Caturtunggal, Depok, Sleman, Yogyakarta 55281 \\ ${ }^{2}$ Center for Agricultural Postharvest Research and Development, Ministry of \\ Agriculture, Jl. Tentara Pelajar No.12, Cimanggu, Bogor, Jawa Barat 16124 \\ *kendriwahyuni@gmail.com
}

\begin{abstract}
Pinctada maxima shells from West Nusa Tenggara has natural minerals called calcite that can be decomposed into $\mathrm{CaO}$ compounds as a green catalyst that heterogeneous, base and environmentally friendly. CaO compounds in the nanometer scale is one option as an alternative substitute or replacement of the use of homogeneous catalysts. The purpose of this study was to test the catalytic activity of $\mathrm{CaO}$ compound from the pearl shells (P. maxima) based on particle size. The catalytic activity test has been measured against the percentage of yield of methyl ester produced by alcoholysis reaction. Characterization of nano-CaO compounds has been done using X-ray powder diffraction (XRD), Brunauer Emmett Teller (BET), scanning electron microscope energy-dispersive $X$-ray spectroscopy (SEM-EDX), transmittance electron microscopy (TEM), while methyl esters has been analyzed using the ASTM method. CaO catalyst on the nanometer-scale have more effective catalytic activity than micrometer scale with the yield percentage of methyl ester obtained are $81,61 \%$ and $30,71 \%$, respectively. The results of methyl ester characterization by ASTM method has shown that methyl ester has specification that are close to diesel oil, so it can be used as an alternative or substitution on diesel engine.
\end{abstract}

Keywords: Heterogeneous catalysts, Pinctada maxima, nanoparticle, Alcoholysis reaction

\begin{abstract}
Abstrak
Kulit kerang mutiara laut (Pinctada maxima) dari Nusa Tenggara Barat memiliki mineral alami kalsit yang dapat didekomposisi menjadi senyawa $\mathrm{CaO}$ sebagai katalis hijau yang bersifat heterogen, basa, dan ramah lingkungan. Senyawa $\mathrm{CaO}$ dalam skala nanometer merupakan salah satu pilihan sebagai alternatif subsitusi atau pengganti dari penggunaan katalis homogen. Tujuan dari penelitian ini adalah untuk melakukan uji aktivitas katalitik senyawa $\mathrm{CaO}$ dari kulit kerang mutiara laut ( $P$. maxima) berdasarkan ukuran partikelnya. Pengujian aktivitas katalitik diukur terhadap persentase yield metil ester yang dihasilkan melalui reaksi alkoholisis. Karakterisasi senyawa nano-CaO menggunakan metode X-ray powder diffraction (XRD), Brunauer Emmett Teller (BET), scanning electron microscope energy-dispersive X-ray spectroscopy (SEMEDX), transmittance electron microscopy (TEM), sedangkan metil ester dianalisis
\end{abstract}


menggunakan metode ASTM. Katalis $\mathrm{CaO}$ berskala nanometer memiliki aktivitas katalitik yang lebih efektif dibandingkan berskala mikrometer dengan persentase yield metil ester yang diperoleh secara berurutan adalah $81,61 \%$ dan $30,71 \%$. Hasil karakterisasi metil ester dengan metode ASTM menunjukkan bahwa metil ester memiliki spesifikasi mendekati minyak diesel sehingga dapat dimanfaatkan sebagai alternatif atau substitusi pada mesin diesel.

Kata kunci: Katalis heterogen, Pinctada maxima, nanopartikel, Reaksi Alkoholisis

\section{Pendahuluan}

Green catalysts atau katalis hijau merupakan katalis yang terbuat dari bahan-bahan alami baik organik maupun anorganik melalui proses produksi yang bersifat green, tanpa penggunaan bahan kimia sebagai doping, biodegradable, dapat didaur ulang, prosesnya sederhana dan hemat biaya, berasal dari sumber daya terbaharukan, tidak beracun, aktivitas katalitik tinggi, bersifat stabil dalam kondisi asam maupun basa (Abdullah et al. 2017; Mosaddegh et al. 2013), ketersediaan melimpah dan limbah air yang dihasilkan sedikit (Macario and Giordano 2013). Yutthalekha et al. (2017) juga melaporkan bahwa green catalyst merupakan katalis yang dikembangkan dengan konsep green technology, bersifat sustainable dan cleaner production sehingga ramah lingkungan. Tujuan utama pengembangan katalis heterogen dengan konsep cleaner production adalah untuk meningkatkan kinerja produksi katalis menggunakan sumber daya alam terbaharukan secara efisien dan aman, termasuk bahan baku, sumber energi dan air, sehingga hemat biaya (Glavi and Lukman 2007; Jegatheesan et al. 2009). Pemerintah Indonesia juga telah menetapkan Undang-Undang Nomor 3 Tahun 2014 tentang pengembangan industri hijau yang difokuskan pada pengembangan dan pemanfaatan energi baru dan terbaharukan, dimana proses produksinya mengutamakan upaya efisiensi dan efektivitas penggunaan sumber daya secara berkelanjutan yang ramah lingkungan (Anonim1 2016).

Limbah kulit kerang yang dapat didekomposisi untuk menghasilkan senyawa $\mathrm{CaO}$ merupakan salah satu bahan baku yang dapat dikembangkan sebagai sumber katalis hijau yang bersifat heterogen sehingga proses pemisahan dan pemurniannya menjadi lebih mudah dan hemat biaya (Lesbani et al. 2013; Zein et al. 2016), alkalinitasnya tinggi, tidak beracun, bersifat green, dan ramah lingkungan (Abdullah et al., 2017; Nurhayati et al. 
2017). Namun, dalam aplikasi menghasilkan rendemen produk yang sedikit karena aktivitas katalitiknya rendah. Tehubijuluw et al. (2014) telah melakukan reaksi transesterifikasi minyak jelantah dalam etanol terkatalisis senyawa $\mathrm{CaO}$ dari kulit telur ayam ras menghasilkan rendemen produk sebesar 36,779\%. Jumlah rendemen produk yang kecil tersebut disebabkan karena antara katalis padat dengan reaktan yang tidak saling larut dalam campuran atau bersifat heterogen, jumlah situs aktif yang rendah, porositas mikro dan ukuran molekul yang besar sehingga membatasi efisiensi transfer massa yang mengakibatkan penurunan laju reaksi serta rendahnya konversi produk yang dihasilkan (Macario and Giordano, 2013; Zabeti et al. 2009; Sani et al. 2013). Dengan demikian aplikasi katalis hijau kurang efisien.

Kinerja aktivitas katalitis hijau yang bersifat heterogen ini dapat ditingkatkan dengan rekayasa ukuran partikel melalui pendekatan nanoteknologi. Ukuran partikel katalis dikecilkan hingga bersakla nanometer yaitu di bawah $100 \mathrm{~nm}$ (SNI ISO/TS 80004-4:2013). Selain itu inovasi katalis heterogen dalam skala nanopartikel diharapkan dapat mengurangi biaya produksi, lebih efisien, bersifat green dan ramah lingkungan. Fatimah (2017) menyebutkan bahwa sintesis nanopartikel merupakan perkembangan teknologi yang berkonsep kimia hijau (green chemistry), penggunaan teknologi yang murah, keberlanjutan tinggi dan aman bagi lingkungan.

Proses rekayasa pengecilan ukuran partikel dengan menggunakan pendekatan nanoteknologi ini dapat meningkatkan luas permukaan partikel katalis yang besar terhadap rasio volume dan situs pori partikelnya menjadi lebih aktif. Dengan demikian proses tumbukan atau mobilisasi antar partikel-partikel reaktan dalam reaksi akan berlangsung lebih aktif dan lebih cepat dengan adanya nano-katalis. Nano-katalis dapat mempercepat waktu reaksi menjadi lebih pendek, reaksi dapat berlangsung pada temperatur kamar, jumlah katalis yang digunakan lebih rendah dan aktivitas katalitiknya tinggi meskipun digunakan secara berulang (reuse). Hal tersebut disebabkan karena katalis dalam ukuran nanopartikel memiliki diameter pori yang besar, area permukaan yang lebih spesifik serta situs aktifnya berjumlah banyak. 
Hasil penelitian Baskar et al. (2017) menggunakan nanopartikel Mg$\mathrm{ZnO}$ sebagai katalis heterogen dalam pembuatan biodiesel dari minyak Mahua diperoleh hasil optimum dalam waktu reaksi 50 menit, temperatur reaksi $40^{\circ} \mathrm{C}$ dan aktivitas katalitiknya tetap stabil pada penggunaan berulang hingga ke 5 dengan FAME di atas $90 \%$. Penggunaan nano-kalsium oksida dari kulit telur sebagai katalis heterogen pada reaksi transesterifikasi dengan microalgae diperoleh kondisi optimum pada konsentrasi nano-kalsium oksida $1,7 \%$ berat dan yield diatas $80 \%$ (Pandit and Fulekar 2017). Gardy et al. (2017) telah memfungsikan $\mathrm{TiO}_{2}$ sebagai nano-katalis yang mampu menghasilkan FAME diatas 90\%. Selain itu, penggunaan katalis dengan ukuran nanopartikel memiliki reaktivitas dan area permukaan yang tinggi sehingga mengakibatkan terjadinya penurunan suhu reaksi. Biokonversi dari limbah padat teh dengan penggabungan katalis $\mathrm{NaOH}$ dan nanopartikel cobalt mampu menghasilkan biodiesel pada kondisi reaksi temperatur kamar (Mahmood and Hussain 2010).

Rekayasa ukuran partikel katalis berskala nanometer (1-100 nm) dapat dilakukan melalui metode top down atau bottom up. Metode top down lebih efektif dalam proses pengecilan ukuran menjadi nanopartikel dibandingkan dengan metode bottom up (Mosaddegh et al., 2013; (Enayati et al. 2009; Pandit and Fulekar, 2017). Metode top down dapat dilakukan melalui teknik sonikasi (ultrasonic milling) atau ball milling. Teknik ball mill merupakan teknik pembuatan nanopartikel menggunakan prinsip energi tumbukan antara sampel dengan bola-bola penggiling dan dinding wadahnya sehingga prosesnya mudah, cepat, dapat dilakukan secara dry milling, pemurnian dan pemisahan mudah, bersifat green, dan ramah lingkungan sehingga mendukung konsep kimia hijau (green chemistry). Tujuan penelitian ini untuk melakukan uji aktivitas katalitik senyawa bio- $\mathrm{CaO}$ dari kulit kerang mutiara laut (Pinctada maxima) berdasarkan ukuran partikelnya.

\section{Metode Penelitian}

\section{Alat}

Peralatan utama yang digunakan adalah Shaker Mill PPF-UG, furnace, oven mermert, disk mill, pengayak ukuran 200 mesh, alat-alat gelas, neraca analitik, Satu set alat refluks, vacuum evaporatory. Instrumen yang digunakan terdiri atas X-Ray Diffraction Rigaku Miniflex600, Scanning Electron 
Microscope-Energy Dispersive X-Ray SU 3500 Hitachi, Transmission Electron Microscopy JEOL/EO JEM1400, Spektrofotometer FTIR Nikolet iS10 dan Brunauer Emmett Teller (BET) Quantachrome Instruments.

\section{Bahan}

Kulit kerang mutiara laut jenis $P$. maxima dari PT. Autore Nusa Tenggara Barat - Indonesia, minyak goreng, etanol teknis, akuades, metanol p.a, $\mathrm{KOH}$ merck, Natrium sulfat anhidrous, kertas saring, satu set alat refluks dan destilasi.

\section{Prosedur Kerja}

\section{Sintesis katalis nano-CaO dari kulit}

\section{P. maxima}

Kulit kerang mutiara jenis $P$. maxima dibersihkan dan dicuci dengan air hangat, diamplas, kemudian dioven pada suhu $110^{\circ} \mathrm{C}$ selama 1 jam. Kulit kerang mutiara yang bersih dan kering digiling menggunakan disk mill sampai menjadi serbuk. serbuk yang diperoleh disaring menggunakan ayakan 200 mesh dilanjutkan proses kalsinasi dengan furnace pada temperatur $650^{\circ} \mathrm{C}$ selama 24 jam untuk memperoleh senyawa kalsium oksida (Roschat et al. 2016). Selanjutnya dilakukan karakterisasi terhadap sifat fisikokimianya.
Proses pembuatan nano-CaO dengan memasukkan serbuk biokalsium oksida dan bola-bola penggiling dengan perbandingan berat 1:10 ke dalam chamber dan ditutup rapat. Kemudian dipasang pada alat Shaker mill sesuai prosedur dan mesin dinyalakan pada kondisi temperatur ruang, waktu 3 jam dan kecepatan kocok 700 rpm. Setelah mesin berjalan sesuai waktu yang telah disetting, mesin dimatikan dan sampel diambil untuk dipisahkan antara serbuk dengan bolabola penggiling. Serbuk yang diperoleh ditimbang dan dihitung rendemennya.

\section{Karakterisasi}

Karakteristik atas sifat fisikokimia nano-CaO dilakukan sesuai ketentuan Badan Standardisasi Nasional SNI/ISO/TS 17200:2015. Sampel powder yang diperoleh dari hasil penggilingan dengan alat Shakel Mill UPP-FG dianalisis ukuran partikel dan kandungan senyawa kimia penyusun dengan menggunakan metode X-Ray Diffraction Rigaku Miniflex600. Kondisi pengoperasian dengan sinar monokromatik $\mathrm{Cu} \quad \mathrm{K} \alpha$, panjang gelombang $\lambda=1.54060 \AA ̊$. Range sudut $2 \theta$ mulai dari $2^{\circ}$ sampai $80^{\circ}$ dengan interval scanning $0,02^{\circ}$ setiap 10 menit pada temperature ruangan. Penentuan 
rata-rata ukuran kristal nanopartikel menggunakan pendekatan dari persamaan Deybe-Scherrer (Pandit and Fulekar, 2017; SNI ISO/TS 17200:2015).

Luas permukaan spesifik nanopartikel dianalisis menggunakan metode Brunauer Emmett Teller/BET (SNI ISO/TS 17200:2015). Sampel sebanyak 0,1-1,0 gram dibuat dalam bentuk pellet dan dioperasikan pada alat dengan kondisi temperatur heating mantle dan kecepatan keluarnya gelembung gas $\mathrm{N}_{2}$ sekitar 3-5 gelembung/detik.

Scanning Electron Microscope SEM SU 3500 Hitachi untuk mengetahui morfologi nanopartikel, dan SEM-Energy Dispersive X-Ray (EDX) digunakan untuk menganalisis komposisi kimia penyusun sampel. Instrumen dioperasikan pada voltase akselerasi penembakan elektron sebesar 5,00 $\mathrm{kV}$ dan WD 5,1 $\mathrm{mm}$ sedangkan EDX dioperasikan pada voltase akselerasi penembakan elektron sebesar 15,00 kV selama 30 detik dengan tingkat resolusi 131,6 eV.

Analisis sampel menggunakan New JEOL TEM (JEM 1400) dilakukan untuk melihat struktur dan bentuk poripori nanopartikel dengan resolusi yang lebih tinggi. Kondisi pengoperasian dilakukan pada voltase akselerasi 120 $\mathrm{kV}$.

\section{Proses reaksi alkoholisis}

Pengujian aktivitas katalis dilakukan pada reaksi alkoholisis antara minyak goreng dengan metanol (rasio molar 1:6), konsentrasi katalis 0,5\% (berat total campuran), temperatur reaksi $60^{\circ} \mathrm{C}$ selama 120 menit. Katalis yang digunakan adalah senyawa $\mathrm{CaO}$ dari kulit kerang mutiara Pinctada maxima berukuran mikrometer dan berukuran nanometer.

Reaksi alkoholisis dilakukan terhadap campuran katalis dan metanol dalam labu alas bulat leher 3 yang dilengkapi dengan kondensor, refluks, magnetik stirer (300 rpm) dan termocouple selama 30 menit. Setelah itu dilakukan penambahan minyak goreng sebanyak $300 \mathrm{ml}$ dan reaksi dihentikan setelah berjalan selama 120 menit. Campuran hasil reaksi didiamkan pada suhu kamar sampai dingin dan dipisahkan antara lapisan-lapisan yang terbentuk. Lapisan bawah merupakan campuran gliserol, sisa metanol dan katalis, lapisan atas adalah campuran antara metil ester, sisa metanol, sisa katalis dan gliserol. Untuk memisahkan campuran-campuran tersebut dilakukan sentrifugasi pada kecepatan putar 9000 rpm selama 10 menit (Gardy et al., 
2017). Sisa metanol berlebih pada produk dipisahkan menggunakan vacum evaporator pada $80^{\circ} \mathrm{C}$ selama 20 menit dan persentase yield metil ester dihitung.

Metil ester yang dihasilkan dikarakterisasi mutunya yang meliputi densitas (ASTM D 1298), viskositas kinematis (ASTM D 445), titik nyala (ASTM D 93), titik kabut (ASTM D 2500), titik tuang dan residu karbon (ASTM D 4530).

\section{Pembahasan}

\section{Sintesis dan karakterisasi CaO}

Kulit kerang $P$. maxima spesifik dari perairan laut Nusa Tenggara Barat dengan kadar abu sebesar 95,80\% memiliki unsur-unsur kimia $\mathrm{Ca}$ $(38,88 \%), \mathrm{O}(50,42 \%), \mathrm{C}(8,12 \%), \mathrm{Cu}$ $(2,02 \%), \mathrm{Na}(0,54 \%)$ dan Si $(0,02 \%)$. Dimana senyawa kimia yang terdeteksi dari hasil analisis XRD berupa $\mathrm{CaCO}_{3}$, $\mathrm{CaO}, \mathrm{SiO}_{2}, \mathrm{CuO}$ dan $\mathrm{Na}_{2} \mathrm{O}$. Kulit kerang yang telah ditepungkan dan diayak menggunakan ayakan berukuran 200 mesh dikalsinasi untuk mendekomposisi senyawa $\mathrm{CaCO}_{3}$ menjadi senyawa gas $\mathrm{CO}_{2}$ dan senyawa $\mathrm{CaO}$ dengan kemurnian tinggi. Proses kalsinasi yang telah dilakukan terhadap serbuk kulit kerang $P$. maxima selama 24 jam pada suhu $650^{\circ} \mathrm{C}$ menghasilkan sifat fisika kimia senyawa $\mathrm{CaO}$ berupa kenampakan serbuk yang berwarna putih, tidak berbau, densitas $1,38 \pm 0,04$ $\mathrm{g} / \mathrm{cm}^{3}$, dan $\mathrm{pH}$ sebesar 12,8 (larutan jenuh 1,65 g/L). Nilai ini hampir sama dengan nilai densitas senyawa $\mathrm{CaO}$ yang dihasilkan dari kulit kerang hasil penelitian Bahri (2015) yaitu sebesar $1,34 \mathrm{~g} / \mathrm{cm}^{3}$. Densitas serbuk kulit telur ayam yang telah dikalsinasi memiliki nilai sebesar 1,23-1,34 g/cm ${ }^{3}$ (Yonata et al., 2017).

Unsur-unsur kimia penyusun senyawa $\mathrm{CaO}$ dari kulit kerang mutiara $(P$. maxima $)$ telah dianalisis menggunakan metode SEM-EDX yang terdiri atas unsur-unsur O $(28,38 \%), \mathrm{Ca}$ (70,08\%), $\mathrm{Cu}(1,30 \%)$ dan $\mathrm{Na}(0,24 \%)$. Unsur C tidak terdeteksi atau tidak muncul, hal ini menunjukkan bahwa proses dekomposisi senyawa $\mathrm{CaCO}_{3}$ pada tepung kulit kerang melalui teknik kalsinasi telah berhasil melepaskan unsur $\mathrm{C}$ dalam bentuk gas $\mathrm{CO}_{2}$ sehingga diperoleh senyawa $\mathrm{CaO}$ dengan jumlah yang tinggi. Jumlah senyawa $\mathrm{CaO}$ yang tinggi ditandai dengan hasil analisis, dimana jumlah unsur $\mathrm{Ca}$ mengalami peningkatan setelah dikalsinasi akibat unsur $\mathrm{Ca}$ yang terlepas dari ikatan senyawa $\mathrm{CaCO}_{3}$. Sedangkan jumlah unsur $\mathrm{O}$ mengalami penurunan setelah dikalsinasi akibat terlepas menguap dalam bentuk gas $\mathrm{CO}_{2}$. 
Keberadaan unsur-unsur kimia $\mathrm{Ca}$ dan $\mathrm{O}$ dalam jumlah yang tinggi pada tepung kulit kerang yang telah dikalsinasi tersebut merupakan unsurunsur penyusun senyawa $\mathrm{CaO}$. Hal ini dibuktikan dengan analisis menggunakan metode SEM-EDX dimana kandungan senyawa $\mathrm{CaO}$ sebesar 98,05\% dan metode XRD seperti yang ditampilkan pada Gambar 1. Gambar 1 menunjukkan bahwa kulit kerang $P$. maxima yang telah dikalsinasi pada suhu $650^{\circ} \mathrm{C}$ selama 24 jam telah menghasilkan senyawa kimia $\mathrm{CaO}$ dengan intensitas puncak difraktogram yang sangat tinggi pada daerah $2 \theta$ sekitar $32,358^{\circ}$ (sesuai JCPDS/Joint comitte for powder diffraction standarts). Tingginya kadar senyawa kimia $\mathrm{CaO}$ pada kulit kerang mutiara laut ( $P$. maxima) ini mengindikasikan bahwa limbah ini berpotensi besar untuk dimanfaatkan sebagai sumber bahan baku pembuatan katalis heterogen yang bersifat basa dan ramah lingkungan.

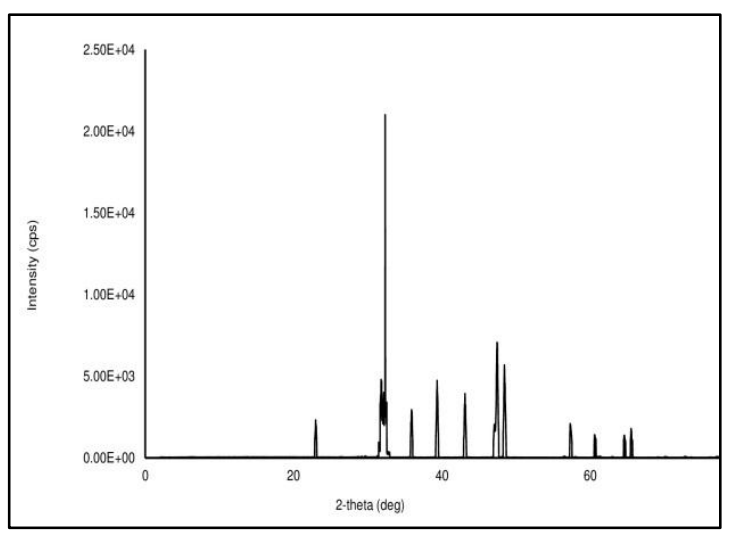

Gambar 1. Spektra XRD serbuk kulit $P$. maxima yang telah dikalsinasi $\left(\mathrm{T}=650^{\circ} \mathrm{C}, \mathrm{t}=\right.$ 24 jam)

Berdasarkan hasil analisis menggunakan metode XRD seperti yang ditunjukkan pada Gambar 1 maka dapat ditentukan ukuran partikel kristalin $\mathrm{CaO}$ dari kulit kerang $P$. maxima melalui persamaan Deybe Scherrer. Hasil perhitungan diperoleh bahwa $\mathrm{CaO}$ ini memiliki ukuran partikel kristalin 442,114 nm. Sedangkan pengukuran luas permukaan spesifik partikel dengan menggunakan metode BET diperoleh hasil sebesar $1,321 \mathrm{~m}^{2} / \mathrm{g}$.

\section{Sintesis dan karakterisasi nano-CaO}

Analisis sifat fisika kimia produk nano-kalsium oksida dalam bentuk serbuk yang dihasilkan dari proses penggilingan menggunakan Shaker mill UPP-FG menunjukkan bahwa sifat fisika kimia nano-CaO tidak jauh berbeda dengan data sifat fisika kimia senyawa $\mathrm{CaO}$ berukuran mikrometer. Karakterisasi mutu nano-CaO sediaan serbuk mengikuti ketentuan dari standar 
yang telah ditetapkan oleh Badan Standardisasi Nasional SNI ISO/TS 17200:2015 yang meliputi komposisi kimia, struktur dan ukuran partikel kristalin, luas permukaan spesifik, morfologi permukaan, bentuk dan morfologi partikel.

Produk nano-kalsium oksida yang diperoleh dari proses produksi pada eksperimen ini memiliki sifat fisik dalam bentuk serbuk, berwarna putih, tidak berbau, densitas $1,74 \pm 0,05 \mathrm{~g} / \mathrm{cm}^{3}$ dan tingkat kebasaan yang terukur sebesar 12,9. Hasil analisis menggunakan metode SEM-EDX menunjukkan bahwa nano-CaO memiliki unsur-unsur kimia yang terdiri atas unsur $\mathrm{Ca}(58,48 \%), \mathrm{O}(24,25 \%), \mathrm{C}$ $(14,05 \%), \mathrm{Cu}(2,22 \%)$, dan Na (1,00\%). Keberadaan unsur $\mathrm{C}$ yang cukup tinggi sebesar $14,05 \%$ dalam produk nano$\mathrm{CaO}$ ini ditemukan dalam bentuk senyawa $\mathrm{CaCO}_{3}$ yang terdeteksi dari hasil analisis menggunakan XRD yang muncul pada daerah $2 \theta$ sekitar $39,28^{\circ}$ dengan intensitas rendah (Gambar 2). Munculnya kembali senyawa $\mathrm{CaCO}_{3}$ dalam produk nanokatalis $\mathrm{CaO}$ ini dikarenakan sifat nano-CaO memiliki luas permukaan yang besar sehingga menyebabkan permukaannya sangat reaktif terhadap kelembaban dan mudah mengikat molekul air dari udara membentuk senyawa kalsium hidroksida $\left(\mathrm{Ca}(\mathrm{OH})_{2}\right)$, senyawa ini memiliki sifat yang mudah menyerap senyawa $\mathrm{CO}_{2}$ dari udara membentuk senyawa yang lebih stabil dalam bentuk kalsium karbonat (Panjaitan et al. 2017; Reddy et al., 2016; Margaretha et al., 2012).

Analisis kuantitatif dengan metode XRF diketahui bahwa kandungan senyawa $\mathrm{CaO}$ sebesar 93,4\%. Keberadaan senyawa $\mathrm{CaO}$ ini juga ditunjukkan oleh data hasil analisis menggunakan XRD (Gambar 2) bahwa puncak difraktogram dengan intensitas yang tinggi muncul pada daerah $2 \theta$ sekitar $32,231^{\circ}$.

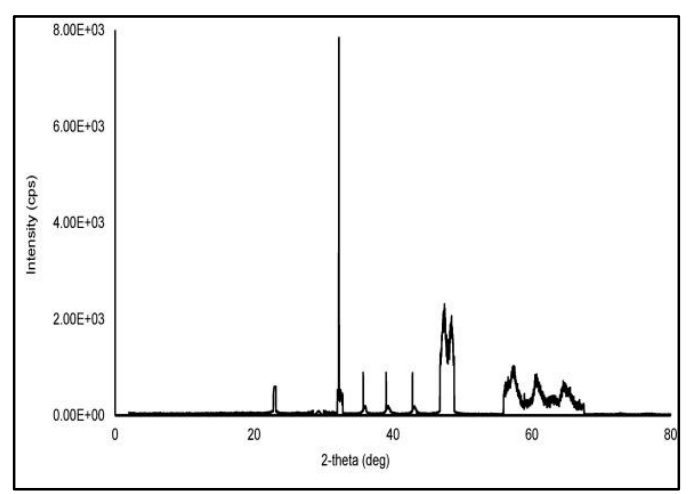

Gambar 2. Spektra XRD nano-kalsium oksida dari kulit $P$. maxima

Hasil analisis XRD pada Gambar 2 menunjukkan bahwa selain senyawa $\mathrm{CaO}$, terdeteksi juga senyawa-senyawa kimia lain, yaitu $\mathrm{CuO}, \mathrm{Na}_{2} \mathrm{O}, \mathrm{CaCO}_{3}$. Keberadaan senyawa-senyawa kimia tersebut yang tergabung ke dalam sampel katalis heterogen $\mathrm{CaO}$ mampu 
bersinergi secara baik dalam berperan sebagai katalis. Hal tersebut dikarenakan senyawa kimia $\mathrm{CuO}$ dan $\mathrm{Na}_{2} \mathrm{O}$ yang stabil dalam bentuk oksida logam memiliki sisi basa kuat dan aktif dalam bentuk pasangan elektron bebas sehingga mampu meningkatkan reaktivitas senyawa logam oksida tersebut sebagai katalis. Widiarti (2012) menyebutkan bahwa $\mathrm{Cu}$ dalam bentuk oksida logam $(\mathrm{CuO})$ memiliki peran sebagai sisi aktif pada reaksi katalitik oksidasi fenol maupun benzene sehingga mampu meningkatkan aktivitas katalitiknya. Begitu pula senyawa $\mathrm{Na}_{2} \mathrm{O}$ merupakan sumber sisi basa yang kuat pada katalis $\mathrm{Na}_{2} \mathrm{O}$ sehingga mampu meningkatkan reaktivitas katalis tersebut (Arva, et al., 2016). Sedangkan senyawa karbonat dalam bentuk $\mathrm{CaCO}_{3}$ mampu berperan sebagai katalis yang reaktif karena memiliki sisi basa yang kuat. Mosaddegh, et al. (2013) menyatakan bahwa bio- $\mathrm{CaCO}_{3}$ dalam ukuran nanometer merupakan katalis heterogen yang memiliki aktivitas katalitik yang tinggi dan efisien dalam reaksi kondensasi pembuatan pyrano[4,3b]pyrans.

Hasil analisis XRD menunjukkan bahwa rata-rata ukuran partikel kristalin kalsium oksida yang telah digiling dengan Shaker mill selama 3 jam sebesar 92,98 nm. Menurut ketentuan SNI ISO/TS 80004-4:2013 bahwa material serbuk yang memiliki ukuran partikel kristalin berskala nanometer (1 - $100 \mathrm{~nm}$ ) tergolong sebagai nanomaterial (Anonim 2017). Dengan demikian produk yang dihasilkan pada eksperimen ini tergolong sebagai serbuk kalsium oksida berskala nanometer dengan nilai luas permukaan spesifik hasil analisis menggunakan metode BET sebesar 10,649 $\mathrm{m}^{2} / \mathrm{g}$. Hasil eksperimen ini mendekati dengan eksperimen yang telah dilakukan oleh Pandit and Fulekar (2017) yang telah membuat nano- $\mathrm{CaO}$ secara top down dari kulit telur ayam. Hasil penelitiannya diperoleh senyawa bio$\mathrm{CaO}$ berskala nanometer sebesar $75 \mathrm{~nm}$ dengan luas permukaan spesifik sebesar $16,4 \mathrm{~m}^{2} / \mathrm{g}$.

Gambar 3 merupakan morfologi permukaan serbuk kalsium oksida berskala mikrometer dan nanometer dari kulit kerang mutiara $P$. maxima. Analisis morfologi permukaan dengan perbesaran yang sama menunjukkan bahwa proses kalsinasi serbuk kulit kerang mutiara mampu memperbaiki morfologi permukaan seperti yang ditunjukkan pada gambar 3b. Serbuk nano-kalsium oksida memiliki 
morfologi permukaan berskala nanometer. Namun tampak dari gambar 3c bahwa sebagian besar partikel nanokalsium oksida mengalami agregasi menjadi partikel dengan ukuran yang lebih besar. Bentuk tiga dimensi dari partikel nano-kalsium oksida yang berhasil dianalisis menggunakan metode TEM ditunjukkan pada gambar 4. Beberapa bagian terlihat bahwa struktur partikelnya mendekati bentuk tetragonal. Hal ini sesuai dengan hasil analisis menggunakan metode XRD, dimana partikel memiliki indeks miller tiga dimensi (197). Namun terlihat juga ada beberapa bagian yang tampak teragregasi sehingga bentuk partikelnya tidak dapat teridentifikasi secara jelas.
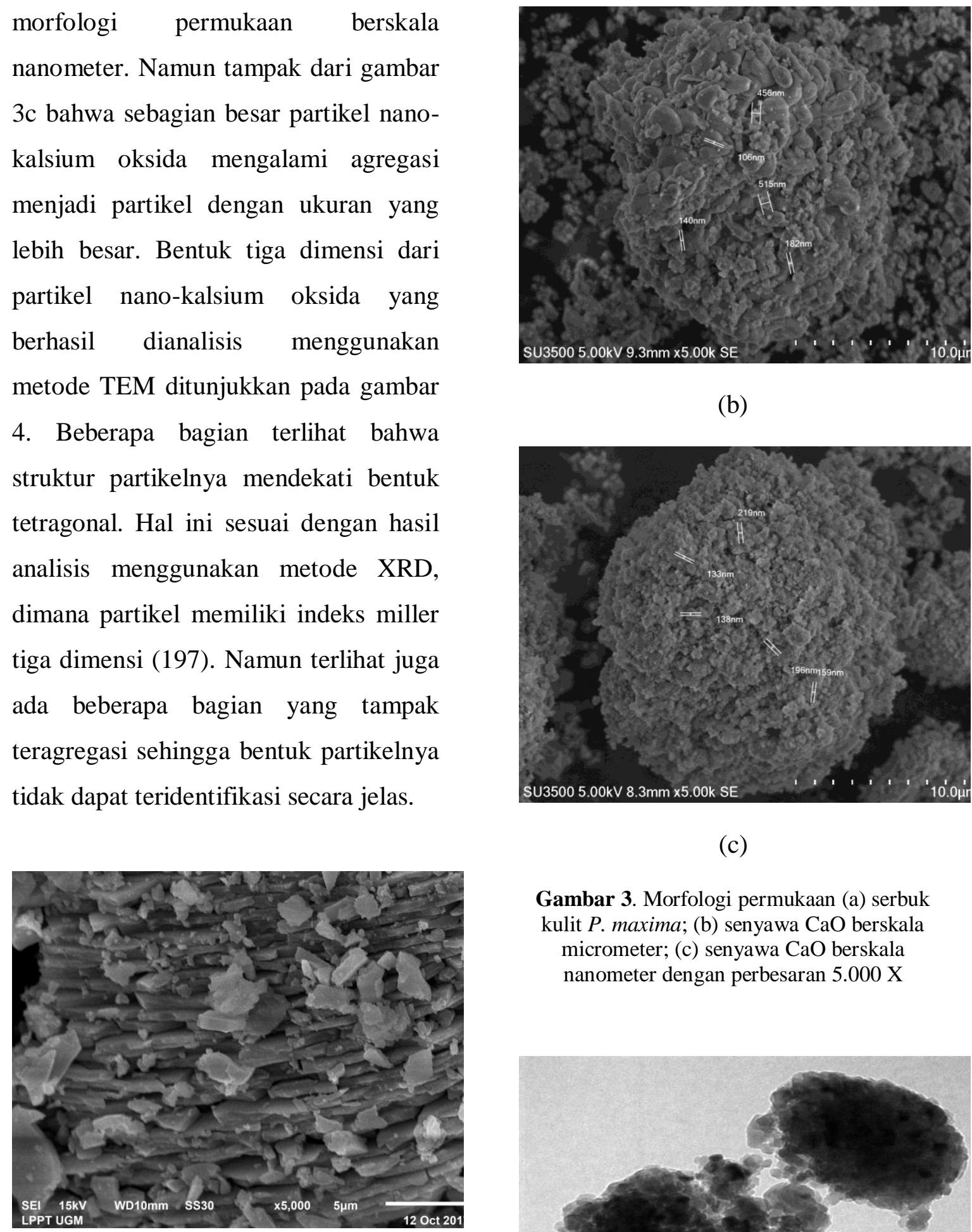

(b)



(c)

Gambar 3. Morfologi permukaan (a) serbuk kulit $P$. maxima; (b) senyawa $\mathrm{CaO}$ berskala micrometer; (c) senyawa $\mathrm{CaO}$ berskala nanometer dengan perbesaran $5.000 \mathrm{X}$

(a)

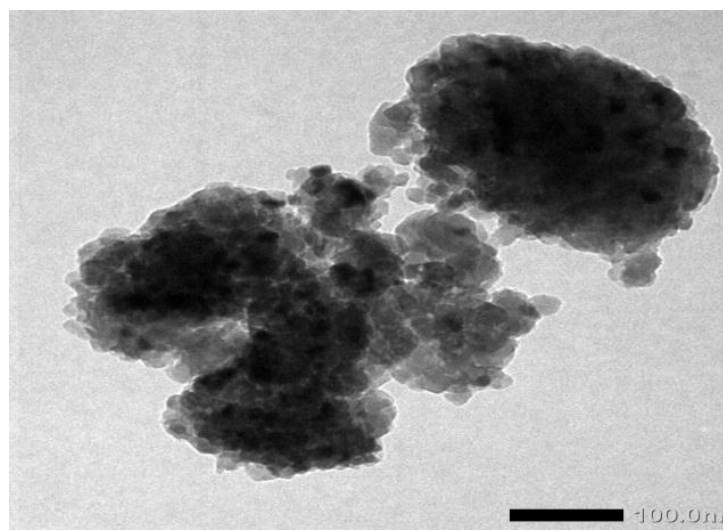

Gambar 4. Hasil analisis metode TEM senyawa nano-CaO dari kulit $P$. maxima 


\section{Uji Aktivitas Katalis Hijau Nano- $\mathrm{CaO}$}

Pengujian aktivitas katalis $\mathrm{CaO}$ dari kulit kerang $P$. maxima dilakukan berdasarkan perbedaan ukuran partikel katalis yaitu berukuran mikrometer dan nanometer. Reaksi alkoholisis telah dilakukan terhadap minyak kelapa sawit dengan metanol terkatalisis senyawa $\mathrm{CaO}$. Senyawa $\mathrm{CaO}$ sebagai katalis digunakan serbuk $\mathrm{CaO}$ dari Merck, $\mathrm{CaO}$ dari kulit kerang $P$. maxima berukuran mikrometer dan nanometer. Kondisi reaksi alkoholisis berjalan pada suhu $60^{\circ} \mathrm{C}$, konsentrasi katais $0,5 \%$, perbandingan mol minyak dengan metanol 1:6 dan waktu reaksi selama 2 jam.

Reaksi kimia diawali antara katalis $\mathrm{CaO}$ dengan metanol membentuk senyawa $\mathrm{CH}_{3} \mathrm{OCaOH}$. Hal ini dimaksudkan agar katalis $\mathrm{CaO}$ memiliki reaktifitas yang lebih besar dalam memecah ikatan kimia gugus ester dalam senyawa trigliserida, sehingga reaksi pembentukkan metil berjalan lebih cepat. Senyawa $\mathrm{CH}_{3} \mathrm{OCaOH}$ bereaksi dengan senyawa trigliserida yang terdapat pada minyak kelapa sawit dengan bantuan energi panas suhu $60^{\circ} \mathrm{C}$ dan proses pengadukkan. Setelah reaksi berjalan selama 2 jam diberhentikan dan didinginkan. Setelah larutan campuran dingin dilakukan proses pemisahan dan pemurnian sehingga diperoleh senyawa metil ester, gliserol dan katalis $\mathrm{CaO}$ yang terbentuk kembali di akhir reaksi.

Tingkat kemampuan aktivitas katalis dalam reaksi metanolisis ditentukan berdasarkan yield metil ester yang diperoleh. Berdasarkan Gambar 5 dapat dilihat bahwa katalis $\mathrm{CaO}$ dari kulit kerang $P$. maxima berskala nanometer memiliki aktivitas katalitik yang lebih efektif dibandingkan katalis $\mathrm{CaO}$ berskala mikrometer, yaitu mampu menghasilkan yield metil ester sebesar $81,61 \%$.

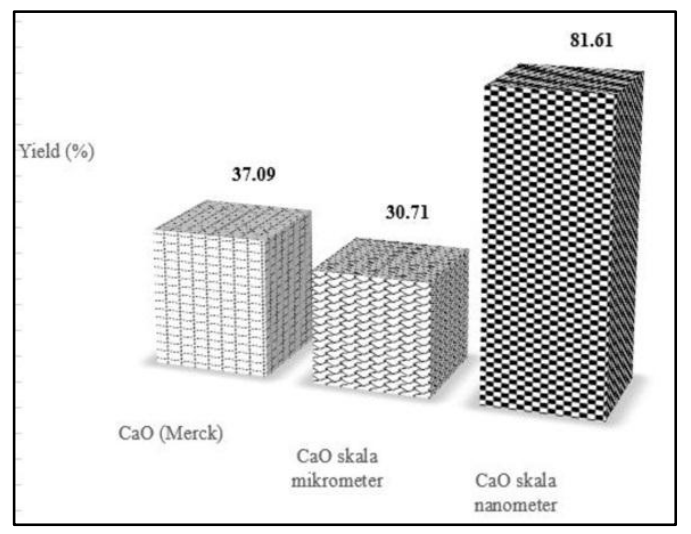

Gambar 5. Yield metil ester hasil reaksi alkoholisis menggunakan katalis heterogen $\mathrm{CaO}$

(Merck), $\mathrm{CaO}$ dari kulit $P$. maxima berskala mikrometer dan nanometer

Gambar 5 menunjukkan bahwa ukuran partikel katalis mempengaruhi tingkat yield metil ester yang dihasilkan. Reaksi transesterifikasi yang 
berjalan selama 2 jam, katalis $\mathrm{CaO}$ dari kulit kerang $P$. maxima skala mikrometer menghasilkan metil ester dengan rata-rata sebesar $30,71 \%$. Sedangkan penggunaan katalis $\mathrm{CaO}$ dari Merck yang lolos ayakan 200 mesh juga menghasilkan yield produk yang rendah yaitu 37,09\%. Rendahnya yield yang diperoleh menunjukkan bahwa katalis $\mathrm{CaO}$ skala mikrometer memiliki aktivitas katalitik yang rendah. Seperti yang telah dilakukan oleh (Taufiq-Yap et al. 2012) bahwa katalis $\mathrm{CaO}$ dari kulit kerang menghasilkan yield metil ester $0 \%$ dalam kondisi reaksi transesterifikasi selama 2 jam, konsentrasi katalis $4 \%$ dan suhu reaksi $65^{\circ} \mathrm{C}$. Namun, hal ini berbeda dengan hasil eksperimen Fatmawati et al. 2018) yang menunjukkan bahwa katalis $\mathrm{CaO}$ dari cangkang keong (Pilla ampullacea) mampu menghasilkan yield metil ester 100\%. Hal tersebut dikarenakan penelitiannya menggunakan rasio molar yang cukup tinggi yaitu 15:1 dan reaksi berjalan lebih lama selama 5 jam. Tingginya rasio molar tersebut menyebabkan kemungkinan reaksi kesetimbangan pada reaksi transesterifikasi lebih banyak berjalan ke arah produk.

Upaya peningkatan kinerja aktivitas katalis heterogen melalui pendekatan nanoteknologi telah menghasilkan katalis heterogen berskala nanometer. Uji coba katalis berskala nanometer, yaitu nano- $\mathrm{CaO}$ dari kulit kerang mutiara laut ( $P$. maxima), dalam reaksi transesterifikasi telah mampu menghasilkan metil ester dengan yield rata-rata sebesar $81,61 \%$. Hal ini menunjukan bahwa ukuran partikel katalis heterogen yang sangat kecil berskala nanometer mengakibatkan efisiensi reaksi yang jauh lebih tinggi dan cepat dibanding pada saat partikel berukuran mikrometer (Hussain et al. 2011; Banković-Ilić et al. 2017; Pandit and Fulekar, 2017; Gardy et al., 2017; Baskar et al., 2017). Hasil ini tidak jauh berbeda dengan literatur, penggunaan katalis nano- $\mathrm{CaO}$ dari kulit kerang dalam reaksi transesterifikasi minyak kedelai menghasilkan metil ester 72,3\% selama 20 menit (Panjaitan et al., 2017). Pandit and Fulekar (2017) juga telah menguji aktivitas katalis nano- $\mathrm{CaO}$ dari kulit telur ayam dalam reaksi transesterifikasi menghasilkan yield metil ester sebesar $86,41 \%$ setelah 3,6 jam reaksi berjalan.

Minyak (metil ester) yang dihasilkan dari reaksi transesterifikasi minyak sawit dalam metanol terkatalisis nano-kalsium oksida dapat dimanfaatkan sebagai sumber alternatif 
bahan bakar mesin diesel. Hasil analisis menunjukkan bahwa metil ester yang diperoleh dari penelitian memiliki spesifikasi yang mendekati spesifikasi standar minyak solar. Hasil analisis tersebut dapat dilihat pada Tabel 1.

Tabel 1. Spesifikasi minyak (metil ester) hasil eksperimen dibandingkan dengan spesifikasi minyak solar standar

\begin{tabular}{|l|l|l|l|}
\hline No & Parameter & $\begin{array}{l}\text { Minyak } \\
\text { ester) } \\
\text { eksperimen }\end{array}$ & $\begin{array}{l}\text { Minyak } \\
\text { hasil } \\
\text { Solar } \\
\text { Standar }\end{array}$ \\
\hline 1 & $\begin{array}{l}\text { Berat jenis pada } \\
15^{\circ} \mathrm{C}(\mathrm{gr} / \mathrm{ml})\end{array}$ & 0,860 & $\begin{array}{l}0,815 \\
0,870\end{array}$ \\
\hline 2 & $\begin{array}{l}\text { Kekentalan } \\
\text { kinematic pada } \\
40^{\circ} \mathrm{C}\left(\mathrm{mm}^{2} / \mathrm{s}\right)\end{array}$ & 4,44 & $2,0-5,0$ \\
\hline 3 & Titik nyala $\left({ }^{\circ} \mathrm{C}\right)$ & 78,5 & Min. 60 \\
\hline 4 & Titik tuang $\left({ }^{\circ} \mathrm{C}\right)$ & 12 & Maks. 18 \\
\hline 5 & $\begin{array}{l}\text { Sisa karbon (\% } \\
\text { berat) }\end{array}$ & 0.08 & Maks. 0,1 \\
\hline
\end{tabular}

*) Spesifikasi bahan bakar minyak jenis minyak solar Keputusan Dirjen Minyak dan Gas Bumi No.3675 K/24/DJM/2006

\section{Kesimpulan}

Kulit kerang mutiara $P$. maxima dari Nusa Tenggara Barat mengandung senyawa $\mathrm{CaO}$ sebesar 98,05\% yang dapat digunakan sebagai katalis hijau. Aktivitas katalis heterogen $\mathrm{CaO}$ dari kulit $P$. maxima berskala nanometer lebih efektif dibandingkan berskala mikrometer sehingga mampu meningkatkan yield produk pada reaksi alkoholisis.

\section{Daftar Pustaka}

Abdullah, S.H.Y.S., Hanapi, N.H.M., Azid, A., Umar, R., Juahir, H., Khatoon, H., and Endut, A., 2017, A Review of BiomassDerived Heterogeneous Catalyst for a Sustainable Biodiesel
Production, Renewable and Sustainable Energy Reviews, 70, 1040-51.

Anonim, 2017, Nanoteknologi - Partikel Nano Dalam Bentuk Serbuk Karakteristik Dan Pengukuran SNI ISO/TS 17200:2015, Jakarta, Badan Standardisasi Nasional.

Anonim, 2016, Indonesia Energy Outlook 2016: Energy Development in Supporting Green Industry 1st ed, Jakarta, Badan Pengkajian dan Penerapan Teknologi.

Anonim, 2017, NanoteknologiKosakata-Bagian 4: Material berstruktur nano SNI ISO/TS 80004-4:2013, Jakarta, Badan Standardisasi Nasional.

Anonim, 2006, Direktur Jenderal Minyak dan Gas Bumi: Spesifikasi Bahan Bakar Minyak Jenis Minyak Solar No. 3675 K/24/DJM/2006, Jakarta, Kementrian Energi dan Sumber Daya Mineral.

Arva, S.P., Helwani, Z. and Saputra, E., 2016, Sintesis fly ash yang dipregnasi dengan $\mathrm{Na}_{2} \mathrm{O}$ sebagai katalis pada proses transesterifikasi minyak sawit off-grade menjadi biodiesel, Jurnal FTEKNIK, 3(1), 1-8.

Banković-Ilić, Ivana B., Marija R. Miladinović, Olivera S. Stamenković, and Vlada B. Veljković, 2017, Application of Nano $\mathrm{CaO}-$ Based Catalysts in Biodiesel Synthesis, Renewable and Sustainable Energy Reviews, 72, 746-60. 
Baskar, G., Gurugulladevi, A. Nishanthini, T., Aiswarya, R., and Tamilarasan, K., 2017, Optimization and Kinetics of Biodiesel Production from Mahua Oil Using Manganese Doped Zinc Oxide Nanocatalyst, Renewable Energy, 103, 641646.

Enayati, M. H., Aryanpour, G.R., and Ebnonnasir, A., 2009, Production of Nanostructured WC-Co Powder by Ball Milling, International Journal of Refractory Metals and Hard Materials, 27, 159-163.

Fatimah, Is, 2017, Synthesis of Metal and Metal Oxide Nanoparticles Using Plant Extract: A Review, Eksakta: Jurnal Imu-Ilmu MIPA, 17(1), 66-85.

Fatmawati, Hikmah, Puspitasari, W., Pujiarti, R., Ardianti, S., and Fatimah, I., 2018, Pengaruh Berat $\mathrm{CaO}$ Dari Cangkang Keong Sawah (Pilla ampullacea) Pada Aktivitasnya Sebagai Katalis Heterogen Pada Konversi Biodiesel Dari Minyak Bekatul, Eksakta: Jurnal Imu-Ilmu MIPA, 18(1), 64-73.

Gardy, J., Hassanpour, A., Lai, X., Ahmed, M.H., and Rehan, M., 2017, Applied Catalysis B : Environmental Biodiesel Production from Used Cooking Oil Using a Novel Surface Functionalised $\mathrm{TiO}_{2}$ NanoCatalyst, Applied Catalysis B, Environmental, 207, 297-310.

Glavi, Peter and Lukman, R., 2007, Review of Sustainability Terms and Their Definitions, Journal of
Cleaner Production, 15, 18751885.

Hussain, S.T., Ali, S.A., Bano, A., and Mahmood, T., 2011, Use of Nanotechnology for the Production of Biofuels from Butchery Waste, 6(31), 72717279 .

Jegatheesan, V., Liow, J.L., Shu, L., Kim, S.H., and Visvanathan, C., 2009, The Need for Global Coordination in Sustainable Development, Journal of Cleaner Production, 17(7), 637-643.

Lesbani, A., Tamba, P., Mohadi, R., and Fahmariyanti, 2013, Preparation of Calcium Oxide From Achatina fulica as Catalyst For Production of Biodiesel From Waste Cooking Oil, Indonesian Journal of Chemistry, 13(2), 176-180.

Macario, Anastasia and Giordano, G., 2013, Catalytic Conversion of Renewable Sources for Biodiesel Production: A Comparison Between Biocatalysts and Inorganic Catalysts, Catal Lett, 143, 159-168.

Mahmood, T., and Hussain, S.T., 2010, Nanobiotechnology for the Production of Biofuels from Spent Tea, African Journal of Biotechnology, 9(6), 858-868.

Mosaddegh, Elaheh, Hassankhani, A., Pourahmadi, S., and Ghazanfari, D., 2013, Ball Mill-Assisted Preparation of Nano- $\mathrm{CaCO}_{3}$ as a Novel and Green Catalyst-Based Eggshell Waste: A Green Approach in the Synthesis of Pyrano[4,3-B]Pyrans, 
International Journal of Green Nanotechnology, 1, 1-5.

Nurhayati, Anita, S., Amri, T.A., and Linggawati, A., 2017, Esterification of Crude Palm Oil Using $\mathrm{H}_{2} \mathrm{SO}_{4} \quad$ and Transesterification Using $\mathrm{CaO}$ Catalyst Derived from Anadara granosa, Indonesian Journal of Chemistry, 17(2), 309-315.

Pandit, P.R., and Fulekar, M.H., 2017, Egg Shell Waste as Heterogeneous Nanocatalyst for Biodiesel Production : Optimized by Response Surface Methodology, Journal of Environmental Management, 198, 319-329.

Panjaitan, F.R., Yamanaka, S., and Kuga, Y., 2017, Soybean Oil Methanolysis over Scallop ShellDerived $\mathrm{CaO}$ Prepared via Methanol-Assisted Dry NanoGrinding, Advanced Powder Technology, 28, 1627-1635.

Roschat, W., Siritanon, T., Yoosuk, B., and Promarak, V., 2016, Rice Husk-Derived Sodium Silicate as a Highly Efficient and Low-Cost Basic Heterogeneous Catalyst for Biodiesel Production, Energy Conversion and Management, 119, 453-462.

Sani, Y.M., Wan M.A.W. Daud, and Aziz, A.R.A., 2013, Solid AcidCatalyzed Biodiesel Production from Microalgal Oil- The Dual Advantage, Journal of Environmental Chemical Engineering, 1, 113-121.

Taufiq-Yap, Y.H., Lee, H.V., and Lau, P.L., 2012, Transesterification of Jatropha curcas Oil to Biodiesel by Using Short Necked Clam (Orbicularia orbiculata) Shell, Energy Exploration \& Exploitation, 30(5), 853-866.

Tehubijuluw, H., Sutapa, I.W., and Lethulur, M., 2014, Waste Cooking Oil Conversion to Biodeisel Catalized By Egg Shell Of Purebred Chiken With Ethanol as A Solvent, Eksakta: Jurnal Imu-Ilmu MIPA, 14(1), $52-64$.

Widiarti, N., 2012, Pengaruh penambahan oksida (CuO) terhadap karakteristik $\mathrm{CuO} / \mathrm{TS}-1$ sebagai katalis alternatif pada reaksi oksidasi benzena menjadi fenol, Sainteknol, 10 (2), 133140.

Yutthalekha, T., Wattanakit, C., and Warakulwit, C., 2017, Hierarchical FAU-Type Zeolite Nanosheets as Green and Sustainable Catalysts for Benzylation of Toluene, Journal of Cleaner Production, 142, 1244-1251.

Zabeti, M., Mohd, W., Wan, A., and Aroua, M.K., 2009, Activity of Solid Catalysts for Biodiesel Production: A Review, Fuel Processing Technology, 90(6), 770-777.

Zein, Y.M., Anal, A.K., Prasetyoko, D., and Qoniah, I., 2016, Biodiesel Production from Waste Palm Oil Catalyzed by Hierarchical ZSM5 Supported Calcium Oxide, Indonesian Journal of Chemistry, 16(1), 98-104. 